\title{
ANALIZA KULTUROWYCH ASPEKTÓW W NIEMIECKIM PRZEKŁADZIE POLSKIEGO KODEKSU KARNEGO
}

\author{
Katarzyna SIEWERT, dr \\ Uniwersytet Kazimierza Wielkiego w Bydgoszczy \\ Instytut Neofilologii i Lingwistyki Stosowanej, \\ ul. Grabowa 2, 85-601 Bydgoszcz \\ e-mail: katarzynasiewert@wp.pl
}

\begin{abstract}
Abstrakt: Przekład tekstów prawnych i prawniczych jest szczególnym rodzajem transferu kulturowego, ponieważ prawo i jego język stanowią integralną część kultury społecznej. Są one nie tylko rezultatem wielowiekowej ewolucji historycznej, lecz także odbiciem specyficznej wizji i sposobu rozumienia rzeczywistości, którą społeczeństwo organizuje za pośrednictwem określonych instytucji prawnych. Dlatego też oprócz wiedzy specjalistycznej od thumacza oczekuje się kompetencji kulturowej, która pozwala zidentyfikować elementy kulturowe w tekście wyjściowym i odtworzyć je w tekście docelowym. W poniższym artykule zostanie przeprowadzona analiza wybranych przykładów pochodzących $\mathrm{z}$ najnowszego przekładu polskiego kodeksu karnego na język niemiecki pod kątem rozwiązań translatorskich zastosowanych w celu oddania odmienności kulturowych na różnych poziomach tekstu.

Słowa kluczowe: odmienność kulturowa, przekład tekstów prawnych, polskie prawo karne, przekład na język niemiecki
\end{abstract}

\section{ANALYSIS OF CULTURAL ASPECTS IN THE GERMAN TRANSLATION OF THE POLISH PENAL CODE}

Abstract: Translation of legal texts is a specific kind of cultural transfer because law and its language are an integral part of social culture. They are not only a result of a centuries-old historical evolution but also a reflection of a specific vision and understanding of the reality which is organised by the particular society through legal institutions. The translator is, therefore, expected to have not only specialist knowledge but also cultural competence which enables him to identify cultural elements in the source text and to reconstruct them in the target text. The present article intends to analyse selected examples from the newest German translation of the Polish penal code, focusing on translation solutions on different levels of the text in order to reconstruct cultural dissimilarity.

Key words: odmienność kulturowa, przekład tekstów prawnych, polskie prawo karne, przekład na język niemiecki

We współczesnej myśli translatologicznej kulturę traktuje się jako nieodłączny element przekładu. W początkowej fazie refleksji naukowej badania translatologiczne koncentrowały się na czysto lingwistycznych aspektach tłumaczenia. Poszerzenie perspektywy badawczej nastąpiło w latach osiemdziesiątych XX w., kiedy to w translatologii rozwinął się nurt, którego przedstawiciele zaczęli postrzegać przekład nie tylko jako transfer językowy, lecz także jako ,transfer kulturowy” (Reiß/Vermeer 1984, 4). Ten ,zwrot kulturowy” skierował uwagę badaczy nie tylko na nowy wymiar przekładu, lecz także pozwolił dostrzec szeroki kontekst kulturowy, w którym osadzony 
Katarzyna Siewert, Analiza kuturowych aspektów w niemieckim przekładzie...

jest przekład wraz ze wszystkimi uwarunkowaniami komunikacyjnymi, pragmatycznymi i społecznymi. Obecnie przyjmuje się, że teksty to nie tylko warstwa słowna będąca efektem zastosowania reguł językowych, lecz komunikaty zdeterminowane sytuacyjnie, społecznie i kulturowo, teksty to - jak pisali Hans G. Hönig i Paul Kußmaul $(1982,58)$ „Zwerbalizowana część socjokultury”.

Mimo wieloletnich badań nad kulturą i jej przejawami dotychczas nie udało się opracować spójnej definicji kultury, ponieważ do dziś jej opis zależy od nurtu prowadzonych badań i stanowiska poszczególnych badaczy. Już w 1954 r. amerykańscy antropolodzy kultury Alfred Kroeber i Clyde Kluckhohn zebrali i zbadali ok. 300 definicji, nie znajdując w tych propozycjach żadnej wspólnej podstawy definicyjnej (por. Reinart 2009, 64). Próby zdefiniowania tego pojęcia tak istotnego dla nauk humanistycznych podejmowano również w teorii translacji (np. Hans J. Vermeer 1986, Gert Wotjak 1993, Ulrich Kautz 2002, Werner Koller 2011). W tym miejscu warto przytoczyć jedną z najczęściej cytowanych definicji, którą w 1986 r. sformułował Hans J. Vermeer w oparciu o definicję Heinza Göhringa inspirowaną z kolei koncepcją kultury amerykańskiego etnologa Warda Goodenougha. Według Hansa J. Vermeera kultura to „ogół norm, konwencji i opinii, którymi w swoim zachowaniu kieruje się jednostka lub społeczeństwo" (Vermeer cyt. za Nord 2011: 74; tł. KS). W takim ujęciu kultura obejmuje ,(1) przedmioty w najszerszym znaczeniu, także niekonkretne, a więc również ,teorie' (...); zachowania (...); (3) oceny" (Vermeer cyt. za Nord 2011, 74; tł. KS). Niestety zacytowana definicja nie pozwala odpowiedzieć na pytanie, czym jest kultura w świetle działalności tłumacza, który pośredniczy w dialogu między kulturami. Z tego względu Christiane Nord dokonała jej modyfikacji, zastępując ogół norm, konwencji i opinii reprezentującymi je ludźmi. W ten sposób powstała następująca koncepcja kultury: „Kultura to społeczność lub grupa ludzi, kierujących się w swoim zachowaniu i działaniu wspólnymi normami, konwencjami oraz ocenami i różniących się $\mathrm{w}$ ten sposób pod względem form zachowania i działania od innych grup i społeczności" (Nord 2011, 74; tł. KS). Tak zdefiniowana kultura jest pojęciem bardzo elastycznym, które można zoperacjonalizować $\mathrm{w}$ przekładzie specjalistycznym. Zaproponowana przez Christianę Nord definicja implikuje, że wspólnoty kulturowe mogą konstytuować się ad hoc. Oprócz (względnie) ustabilizowanych wspólnot kulturowych, jakimi są państwa, narody czy plemiona, tak określone pojęcie włącza w swój zakres również grupy specjalistów określonej dziedziny posiadających wspólne normy zachowań i ocen, wywodzących się z różnych wspólnot językowych, np. angielsko- i niemieckojęzyczni astrofizycy w odróżnieniu od grupy innych specjalistów, np. informatyków. W takim rozumieniu kultury język, postrzegany jako jeden z jej przejawów, może, lecz nie musi stanowić jej konstytutywnej cechy. W określonej wspólnocie językowej różnice kulturowe mogą bowiem występować w innych obszarach zachowań niż zachowania językowe. Zdarza się również, że podobieństwa kulturowe można zaobserwować w społecznościach, których członkowie posługują się różnymi językami. Przyczyną takiego stanu rzeczy są wspólne uwarunkowania historyczne, polityczne i wspólne tradycje (por. Nord 2011, 75). Co ważne, koncepcja kultury Christiane Nord uwzględnia fakt, iż teksty wyjściowe nie odzwierciedlają konwencji zachowania wszystkich użytkowników danego języka, lecz jedynie tej grupy, do której należy twórca tekstu lub nadawca, oraz/lub tej grupy, dla której tekst jest przeznaczony. Podobnie jest z translatami, które rzadko przeznaczone są dla wszystkich użytkowników języka 


\section{Comparative Legilinguistics 17/2014}

docelowego. Oznacza to, że w każdym indywidualnym przypadku w ramach konkretnego zlecenia tłumaczeniowego należy ustalić istotne różnice $\mathrm{w}$ formach zachowań grup użytkowników języka wyjściowego i języka docelowego. Ogół cech różniących ich zachowania będzie stanowić „specyfikę kulturową”, rozumianą jako występowanie pewnych cech jedynie $\mathrm{w}$ jednej $\mathrm{z}$ kultur, zidentyfikowanych $\mathrm{w}$ drodze konfrontacji wchodzących w grę kultur (por. Nord 2011, 76).

Powyższe rozważania są ciekawe $\mathrm{z}$ punktu widzenia przekładu specjalistycznego, ponieważ w przypadku różnych dziedzin wiedzy i związanej z nimi komunikacji specjalistycznej kulturę należy rozpatrywać w szerokim, wielowymiarowym kontekście, wykraczającym poza tradycyjne ramy narodowe. W komunikacji specjalistycznej większe znaczenie odgrywa przynależność do określonej dyscypliny niż przynależność do określonej kultury narodowej czy językowej. Można zatem powiedzieć, że w komunikacji specjalistycznej dominującą rolę odgrywa kultura specjalistyczna, którą tworzą ,specyficzne umiejętności wytworzone przez specjalistę na potrzeby komunikacji profesjonalnej w obrębie odpowiednich wspólnot specjalistów" (Grucza 2006, 37). Położenie akcentu na kulturę specjalistyczną, opartą nie tylko na wspólnych treściach, lecz także na wspólnych wartościach, doprowadziło między innymi do tego, że w tłumaczeniu specjalistycznym funkcję przekładu, polegającą na pośredniczeniu między różnymi obszarami kulturowymi, traktowano jako funkcję drugorzędną (por. Sandrini 2010, 39). Znamienne dla takiego podejścia jest stanowisko Ericha Prunča (2000, 28), który uważa, że w zhomogenizowanej kulturowo sytuacji komunikacyjnej, jaka ma miejsce na konferencjach specjalistów z określonej branży, tłumaczenie sprowadza się do uproszczonej formy translacji zwanej translacja homologiczna. Polega ona na odtworzeniu w tekście docelowym kontekstowo jednoznacznych elementów powierzchni tekstu wyjściowego za pomocą odpowiednich elementów języka docelowego (por. Prunč 2000, 23). Wydawałoby się więc, że komunikacja, której podstawę stanowi wiedza specjalistyczna, jest pozbawiona wymiaru kulturowego. Okazuje się jednak, że jest inaczej, ponieważ także dyscypliny naukowe są produktami uwarunkowanego kulturowo podziału pracy i z tego względu mogą też wykazywać odmienną strukturę. I tak na przykład mówi się o medycynie chińskiej i medycynie europejskiej (por. Fleischmann/Schmitt 2004, 534-535). Jak słusznie podkreśla Peter Sandrini (2006, 112), kulturę każdej dyscypliny tworzą swoiste wartości i normy leżące u podstaw metodologii i ideologii. Poza tym teksty specjalistyczne moga zawierać tzw. realia, czyli nośniki tożsamości kultury narodowej lub etnicznej będące elementami historii, polityki, itd., którymi są zwłaszcza szczególnego rodzaju obiekty kultury materialnej i społecznej, nazwy instytucji życia społecznego i politycznego, itp., niemające w kulturze docelowej swojego odpowiednika ani w postaci przedmiotu, pojęcia, ani też nazwy (por. Markstein 2006, 288; Fleischmann/Schmitt 2004, 355). Kultura może znaleźć swój wyraz na różnych poziomach tekstu specjalistycznego, do których należy między innymi gatunek tekstu i jego funkcje, udział elementów niewerbalnych, format i układ graficzny, typografia, makrostruktura tekstu, zawartość informacyjna, styl, morfologia, hierarchia i cechy definicyjne pojęć (por. Fleischmann/Schmitt 2004, 538). Jak stwierdza Radegundis Stolze (2010, 13), kulturowe konwencje dotyczące struktury tekstu specjalistycznego mogą stanowić niekiedy wręcz poważny problem tłumaczeniowy.

Tłumacz tekstów specjalistycznych jest stale konfrontowany $\mathrm{z}$ ich specyficznym charakterem na płaszczyźnie leksykalnej i składniowej, $\mathrm{z}$ obecnością terminów 
Katarzyna Siewert, Analiza kuturowych aspektów w niemieckim przekładzie...

bezekwiwaletnych oraz nietypową makrostrukturą tekstów realizujących określony wzorzec gatunkowy właściwy dla danej dziedziny (por. Kubacki 2013, 165). Będąc nie tylko pośrednikiem między językami, lecz także między kulturami, tłumacz powinien posiadać kompetencję kulturową, zwłaszcza w tłumaczeniu tekstów specjalistycznych opisujących charakterystyczne dla danego społeczeństwa przejawy życia społecznego, takie jak prawo, gospodarka i administracja. Dla zilustrowania odmienności kulturowych na różnych poziomach tekstu i rozwiązań translatorskich, mających na celu ich odzwierciedlenie w docelowym tekście specjalistycznym, w niniejszym artykule wybrano dziedzinę prawa. Kulturowe aspekty tłumaczenia prawniczego zostaną zaprezentowane na wybranych przykładach pochodzących z najnowszego przekładu polskiej ustawy Kodeks karny z dnia 6 czerwca 1997 r. na język niemiecki, który ukazał się nakładem Wydawnictwa C.H. Beck w 2012 roku i który został przygotowany przez pięcioosobowy zespół tłumaczy (Joanna Chudzik, Michał Jakowczyk, Kaja Kowalski, Andreas Krajewski, Kamila Matthies).

Przed przystąpieniem do analizy warto zwrócić uwagę na wzajemne relacje zachodzące między kulturą i prawem, które stanowi integralną i ważną część każdej kultury społecznej. Tysiącletnia historia kultury i prawa wyraźnie pokazuje wzajemne zależności między rozwojem prawa i wpływami różnorodnych prądów intelektualnych w różnych okresach historycznych (por. Sandrini 1999, 9). Historia prawa określonej kultury zależy od jej historii, otoczenia, gospodarki, filozofii i teologii, literatury i sztuki (por. Hattenhauer 1980: 183). Prawo i jego język są nie tylko rezultatem wielowiekowej ewolucji historycznej, lecz także odbiciem specyficznej wizji i sposobu rozumienia rzeczywistości, którą społeczeństwo organizuje za pośrednictwem określonych instytucji prawnych (por. Pieńkos 1999, 129). Dlatego też, jak pisze Sieglinde Pommer (2008, 1718), znaczenia instytucji prawnych nie można w pełni zrozumieć, nie postrzegając ich jako części kultury społeczeństwa, a kultury nie można w pełni zrozumieć, nie biorąc pod uwagę formy prawa. Narodowe systemy prawne są głęboko zakorzenione w specyficznej tradycji i kulturze prawnej, ponieważ prawo jako zjawisko społeczno-kulturowe jest zawsze związane $\mathrm{z}$ kulturą określonego społeczeństwa i jego jurysdykcją. W tym kontekście wymowna jest metafora Knuta Ipsena (2000, 408), przedstawiająca prawo jako „szatę narodu”, jako wyraz i efekt jego woli do samostanowienia. Tak więc porządek prawny każdego kraju, obejmujący normy prawne, ogół aktów stosowania prawa oraz strukturę organów i instytucji związanych z obrotem prawnym, stanowi swoisty zbiór reguł prawnych odpowiadający aspiracjom i zwyczajom tego kraju. Zauważył to już Monteskiusz, mówiąc, że ,rzadki to traf, aby prawa jednego narodu mogły się nadać drugiemu” (Monteskiusz cyt. za Pieńkos 1999, 101).

Wobec tak ścisłych korelacji zachodzących między prawem a kulturą danego społeczeństwa przekład tekstów prawnych i prawniczych jest szczególnym rodzajem transferu kulturowego, ponieważ tłumacz przenosi treści porządku prawnego określonej wspólnoty kulturowej do porządku prawnego wspólnoty kulturowej żyjącej w odmiennych warunkach społeczno-politycznych (por. Pieńkos 1999, 150). Stąd też oprócz wiedzy specjalistycznej od tłumacza oczekuje się także kompetencji kulturowej, która pozwala na zidentyfikowanie elementów kulturowych w tekście wyjściowym oraz ich otworzenie w tekście docelowym. Umiejętność dostrzegania śladów kultury w tego rodzaju tekstach, w których jasność i precyzja sformułowań ma kluczowe znaczenie, jest o tyle ważna, iż tłumacz wywodzący się z innej kultury może nie być w stanie właściwie 


\section{Comparative Legilinguistics 17/2014}

zinterpretować implicytnych treści zawartych w tekście (por. Stolze 2010, 13). Stwierdzenie to nabiera szczególnego znaczenia w odniesieniu do tekstów prawnych, ponieważ zawarty w nich komunikat w odróżnieniu od komunikatu zawartego w innych tekstach specjalistycznych nadany jest za pomocą kodu lub kodów, których odzwierciedleniem są pojęcia prawne. Aby odkodować komunikat i oddać go następnie w tekście docelowym, tłumacz musi zinterpretować tekst nie tylko pod względem językowym, ale także i prawnym (por. Pieńkos 1999, 121). Cechą charakterystyczną pojęć prawnych występujących w tekstach prawnych w postaci terminów prawnych jest ich kontekstowość. Podkreślić należy, że nie chodzi tutaj jedynie o kontekst językowy, ale również o kontekst systemowy, czyli o właściwości systemu prawa, do którego należą przepisy zawierające dany termin, jak i wreszcie o kontekst funkcjonalny. Ten ostatni tworzy cały szereg zjawisk społeczno-politycznych, ekonomicznych, ocen i regul społecznych, w jakich przepis zawierający dany termin został ustanowiony lub jest stosowany albo przestrzegany (por. Kalinowski/Wróblewski 1987, 18). Tak złożony proces interpretacji istniejących kontekstów wymaga dogłębnej wiedzy specjalistycznej i znajomości kultury prawnej w obu językach.

\section{Poziom leksykalny}

Elementy kulturowe w tekstach prawnych najłatwiej jest odnaleźć w warstwie leksykalnej. Język prawny posługuje się konwencjonalnymi określeniami instytucji prawnych, na które składają się terminy będące ich nazwami zdefiniowanymi w odnośnych przepisach oraz całe zwroty utrwalone często wielowiekową tradycją ich użycia (por. Kierzkowska 2002, 16). Terminy i utarte wyrażenia odnoszą się zazwyczaj do pojęć charakterystycznych dla danego systemu prawnego, związanego z typowymi dla niego realiami kulturowymi. Pojęcia prawne tworzące system prawny są - jak już wspomniano na wstępnie - wyrazem kategoryzacji rzeczywistości pozajęzykowej specyficznej dla danego narodu. Tak swoiście skonstruowany system pojęciowy Tomasz Gizbert-Studnicki nazywa ,prawnym obrazem świata” (por. Gizbert-Studnicki 1993, 308-309). Z uwagi na to, iż systemy prawne poszczególnych krajów różnią się, niekiedy nawet znacznie, to odmienne są także obrazy świata. To z kolei znajduje swoje odzwierciedlenie w pojęciowej nieprzystawalności terminologii różnych systemów prawnych. Teksty prawne zawierają więc terminy, które występują w systemie prawnym danego kraju i nie mają swojego odpowiednika w systemie prawnym innego kraju, czyli z przekładowego punktu widzenia są bezekwiwalentne. Według Joanny KrzemińskiejKrzywdy (por. Kubacki 2012, 172) terminy te tworzą kategorię terminów z prawdziwą ekwiwalencją zerową. Drugą kategorię natomiast stanowią terminy bezekwiwalentne pozorne, będące swoistymi zestawieniami wyrazów lub terminów w drugim języku lub też terminami stricte prawniczymi niewystępującymi w aktach prawnych, czyli niebędące terminami prawnymi.

W konfrontacji polskiego i niemieckiego prawa karnego przykładami terminów z prawdziwą ekwiwalencją zerową są czyn zabroniony, nawiąza, przestęsstwo podobne, społeczna szkodliwość, występek o charakterze chuligańskim.

W przypadku terminów bezekwiwalentnych zaleca się stosowanie określonych technik translatorskich, z których najważniejsze to: ekwiwalent denotatywny (ekwiwalent zorientowany na język źródłowy, czyli termin w języku docelowym, niekojarzący się 
Katarzyna Siewert, Analiza kuturowych aspektów w niemieckim przekładzie...

odbiorcom $\mathrm{z}$ denotatem podobnym do denotatu opisywanego przez termin $\mathrm{w}$ języku wyjściowym), ekwiwalent konotatywny (ekwiwalent zorientowany na język docelowy, kojarzący się odbiorcom $\mathrm{z}$ denotatem podobnym do denotatu opisywanego przez termin w języku wyjściowym), ekwiwalent seminaturalny (modyfikacja ekwiwalentu naturalnego, łącząca $\mathrm{W}$ sobie cechy ekwiwalentu naturalnego $\mathrm{z}$ cechami terminu źródłowego), kalka językowa (ekwiwalent językowy utworzony za pomocą rodzimych elementów języka według wzoru semantycznego języka obcego), zapożyczenie proste (wyraz lub zwrot przejęty z języka wyjściowego w niezmienionej formie), zapożyczenie naturalizowane (zapożyczenie o formie dostosowanej do wymogów fonetycznych języka docelowego), neologizm (nowo utworzony termin, nieznany w języku docelowym) ekwiwalent opisowy oraz ekwiwalent frazeologiczny (wyrażenia utworzone z zachowaniem konwencji języka docelowego przyjętych dla związków międzywyrazowych, tzw. kolokacji) (por. Kierzkowska 2002, 118-123; Kubacki 2012, 170-172).

Przyjrzyjmy się teraz technikom, jakie w thumaczeniu wyżej przytoczonych terminów polskiego prawa karnego wykorzystali tłumacze w przekładzie ustawy Kodeks karny na język niemiecki. Technika kalki językowej została zastosowana w tłumaczeniu następujących terminów:

\section{Przykład 1.}

Art. 1. $\S 1$. Odpowiedzialności karnej podlega ten tylko, kto popełnia czyn zabroniony pod groźbą kary przez ustawę obowiązującą w czasie jego popełnienia. Art. $1 \S 1$. Strafrechtlicher Verantwortlichkeit unterliegt nur derjenige, der eine verbotene Tat begeht, die zum Zeitpunkt der Tatbegehung nach dem geltenden Gesetz mit Strafe bedroht ist.

\section{Przykład 2.}

Art. 115. § 3. Przestępstwami podobnymi są przestępstwa należące do tego samego rodzaju; przestępstwa z zastosowaniem przemocy lub groźby jej użycia albo przestępstwa popełnione w celu osiągnięcia korzyści majątkowej uważa się za przestępstwa podobne.

Art. 115. § 3 Ähnliche Straftaten sind Straftaten, die der gleichen Art angehören; Straftaten mit Gewaltanwendung oder Drohung ihrer Anwendung oder Straftaten, die mit dem Ziel begangen wurden, einen Vermögensvorteil zu erlangen, werden als ähnliche Straftaten angesehen.

\section{Przykład 3.}

Art. 1. $\S 2$. Nie stanowi przestępstwa czyn zabroniony, którego społeczna szkodliwość jest znikoma.

Art. $1 . \S 2$. Eine verbotene Tat ist keine Straftat, wenn ihre soziale Schädlichkeit gering ist.

Zaproponowane rozwiązanie translatorskie można ocenić pozytywnie, ponieważ są one trafne $\mathrm{z}$ punktu widzenia dwóch zasad przyjętych $\mathrm{w}$ tłumaczeniu prawniczym, a mianowicie zasady transparentności thumaczenia i relewancji (por. Pommer 2008, Stolze 2005). 
Dla terminów nawiązka i występek o charakterze chuligańskim utworzono neologizmy:

Przykład 4.

Art. 39. 6) nawiązka (...).

Art. 39. 6) die Geldauflage (...).

\section{Przykład 5.}

Art. 57a. § 1. Skazując za występek o charakterze chuligańskim, sąd wymierza karę przewidzianą za przypisane sprawcy przestępstwo w wysokości nie niższej od dolnej granicy ustawowego zagrożenia zwiększonego o połowę.

Art. 57a. § 1. Bei einer Verurteilung wegen eines Rowdyvergehens bemisst das Gericht die vorgesehene Strafe für die dem Täter zugeschriebene Straftat nicht unter der gesetzliche angedrohten unteren Grenze, die um die Hälfte erhöht wird.

Wydaje się, że zaproponowane ekwiwalenty niemieckie nie oddają w pełni treści znaczeniowej terminów polskich. W pierwszym przypadku lepszym rozwiązaniem byłoby odwołanie się do istniejącego w języku prawniczym terminu Buße oznaczającego obowiązek uiszczenia pewnej kwoty na rzecz organizacji pożytku publicznego za popełniony występek. Zakres znaczeniowy Buße pokrywa się wprawdzie po części z zakresem znaczeniowym nawiązki, lecz oba terminy można by uznać za ekwiwalenty funkcjonalne. $\mathrm{Z}$ punktu widzenia postulowanej transparentności tłumaczenia prawniczego, za odpowiednie rozwiązanie należy uznać zaproponowany przez Alinę i Agnieszkę Kilian ekwiwalent Bußzahlung, który nie jest dla odbiorcy języka docelowego mylący, ponieważ jego forma sygnalizuje inne znaczenie niż znaczenie funkcjonującego w niemieckim systemie prawnym terminu $B u ß e$. Ekwiwalent drugiego polskiego terminu jest o tyle nietrafny, iż po pierwsze na podstawie formy Rowdyvergehen trudno jest odkodować jego znaczenie, a po drugie człon Rowdypraktycznie nie tworzy złożeń w języku niemieckim. Bardziej transparentnym rozwiązaniem translatorskim byłaby w tym przypadku kalka językowa Vergehen mit rowdyhaftem Charakter, tym bardziej, że nawiązuje ona do historycznego pojęcia andere Delikte mit rowdyhaftem Charakter, które funkcjonowało w byłej NRD i występowało jako termin prawny w $§ 215$ kodeksu karnego z 1 lipca 1968 r. (por. Waibel 2007, 16).

Dla drugiej kategorii terminów bezekwiwalentnych, czyli terminów z pozorną ekwiwalencją zerową, można przytoczyć następujące przykłady terminów prawnych: obraza uczuć religijnych, odpowiedzialność karna, rejestr skazanych i zamach terrorystyczny. Ekwiwalenty terminów obraza uczuć religijnych i zamach terrorystyczny w języku niemieckim można przy tym zaklasyfikować do kategorii specyficznych zestawień wyrazów, a niemieckie ekwiwalenty terminów odpowiedzialność karna i rejestr karny do kategorii terminów prawniczych. Oto propozycje przekładów:

\section{Przykład 6.}

Art. 196. Obraza uczuć religijnych. Kto obraża uczucia religijne innych osób, znieważając publicznie przedmiot czci religijnej lub miejsce przeznaczone do publicznego wykonywania obrzędów religijnych, podlega grzywnie, karze ograniczenia wolności albo pozbawienia wolności do lat 2 . 
Katarzyna Siewert, Analiza kuturowych aspektów w niemieckim przekładzie...

Art. 196. Verletzung der religiösen Gefühle. Wer die religiösen Gefühle anderer Personen verletzt, indem er einen Gegenstand der religiösen Ehre oder einen Ort der öffentlichen Ausübung von religiösen Zeremonien öffentlich beleidigt, wird mit Geldstrafe, Freiheitsbeschränkungsstrafe oder Freiheitsstrafe bis zu 2 Jahren bestraft.

\section{Przykład 7.}

Art. 140.§ 1. Zamach terrorystyczny. Kto, w celu osłabienia mocy obronnej Rzeczypospolitej Polskiej dopuszcza się gwałtownego zamachu na jednostkę Sił Zbrojnych Rzeczypospolitej Polskiej, niszczy lub uszkadza obiekt albo urządzenie o znaczeniu obronnym, podlega karze pozbawienia wolności od roku do lat 10 .

Art. 140. § 1. Terroristischer Angriff. Wer, mit dem Ziel, die Verteidigungskraft der Republik Polen zu schwächen, einen gewaltsamen Angriff auf eine Einheit der Streitkräfte der Republik Polen ausübt, ein Verteidigungobjekt [sic!] oder eine Vorrichtung, die für die Verteidigung von Bedeutung ist, zerstört oder beschädigt, wird mit Freiheitsstrafe von einem Jahr bis zu 10 Jahren bestraft.

Propozycje ekwiwalentów przekładowych powstałych w wyniku zastosowania techniki kalki językowej można uznać za właściwe, ponieważ są one transparentne i zrozumiałe dla odbiorcy posługującego się językiem docelowym, tym bardziej, że zacytowane przepisy prawne stanowią eksplikacje semantyczne.

Druga wyekscerpowana grupa ekwiwalentów terminów polskich to ekwiwalenty konotatywne, zaczerpnięte z niemieckiej terminologii prawniczej:

\section{Przykład 8.}

Art. 1. $\S 1$. Odpowiedzialności karnej podlega ten tylko, kto popełnia czyn zabroniony pod groźbą kary przez ustawę obowiązującą w czasie jego popełnienia.

Art. $1 \S 1$. Strafrechtlicher Verantwortlichkeit unterliegt nur derjenige, der eine verbotene Tat begeht, die zum Zeitpunkt der Tatbegehung nach dem geltenden Gesetz mit Strafe bedroht ist.

\section{Przykład 9.}

Art. 106. Z chwilą zatarcia skazania uważa się je za niebyłe; wpis o skazaniu usuwa się z rejestru skazanych.

Art. 106. Mit dem Zeitpunkt der Tilgung der Verurteilung wird die Verurteilung als gegenstandslos angesehen; die Eintragung der Verurteilung wird aus dem Strafregister gelöscht.

Jeśli chodzi o termin odpowiedzialność karna, to należy zauważyć, iż autorzy nie są konsekwentni w swoich działaniach translatorskich, ponieważ w art. $21 \S 1$ i 2 stosują odmienne rozwiązania niż w art. 1 i 2, naruszając tym samym obowiązującą w tłumaczeniu specjalistycznym zasadę niestosowania synonimów dla jednego i tego samego terminu:

Przykład 10.

Art. $21 \S 1$. Okoliczności osobiste, wyłączające lub łagodzące albo zaostrzające odpowiedzialność karną, uwzględnia się tylko co do osoby, której dotyczą. 


\section{Comparative Legilinguistics 17/2014}

Art. 21. § 1. Persönliche Umstände, die die strafrechtliche Verantwortung ausschließen, schärfen oder mildern, gelten nur für die Person, bei der sie vorliegen.

\section{Przykład 11.}

Art. $21 \S 2$. Jeżeli okoliczność osobista dotycząca sprawcy, wpływająca chociażby tylko na wyższą karalność, stanowi znamię czynu zabronionego, współdziałający podlega odpowiedzialności karnej przewidzianej za ten czyn zabroniony, gdy o tej okoliczności wiedział, chociażby go nie dotyczyła.

Art. 21. § 2. Ist der persönliche Umstand beim Täter ein Tatbestandsmerkmal, der sich wenn auch nur strafschärfend auswirkt, ist der Mitwirkende wegen der gegebenen verbotenen Tat zu bestrafen, wenn er den Umstand kannte, auch wenn er ihn selbst nicht betraf.

\section{Poziom składniowy}

Analiza porównawcza struktur syntaktycznych polskiego i niemieckiego kodeksu karnego wykazała odmienności w stosowaniu poszczególnych konstrukcji dla wyrażenia normatywnego charakteru przepisów prawnych. W polskim kodeksie karnym normatywność wyraża się najczęściej za pomocą czasownika w czasie teraźniejszym trybu oznajmującego, czasownika modalnego móc z bezokolicznikiem oraz czasownika w trzeciej osobie czasu teraźniejszego z zaimkiem zwrotnym się. Za przykład niech posłuży art. $6 \S 1$ oraz art. $10 \S 3 \mathrm{kk}$ :

Przykład 12.

Art. $6 \S 1$. Czyn zabroniony uważa się za popełniony w czasie, w którym sprawca działał lub zaniechał działania, do którego był obowiązany.

\section{Przykład 13.}

Art. 10. $\S 3$. W wypadku określonym w $\S 2$ orzeczona kara nie może przekroczyć dwóch trzecich górnej granicy ustawowego zagrożenia przewidzianego za przypisane sprawcy przestępstwo; sąd może zastosować także nadzwyczajne złagodzenie kary.

W niemieckim kodeksie karnym oprócz czasownika w czasie teraźniejszym trybu oznajmującego i czasownika modalnego kann z bezokolicznikiem normatywny charakter przepisów odzwierciedlają przede wszystkim konstrukcje w stronie biernej stadialnej lub czynnościowej oraz konkurencyjne formy strony biernej składające się z czasownika posiłkowego sein i bezokolicznika z partykułą zu. Jako przykład zacytujmy $\S 2$ pkt 6 i $\S 57$ a StGB:

Przykład 14.

$\S 2$. (6) Über Maßregeln der Besserung und Sicherung ist, wenn gesetzlich nichts anderes bestimmt ist, nach dem Gesetz zu entscheiden, das zur Zeit der Entscheidung gilt.

Przykład 15. 
Katarzyna Siewert, Analiza kuturowych aspektów w niemieckim przekładzie...

$\S 57 \mathrm{a}$. Ist auf lebenslange Freiheitsstrafe als Gesamtstrafe erkannt, so werden bei der Feststellung der besonderen Schwere der Schuld (§ 57a Abs. 1 Satz 1 Nr. 2) die einzelnen Straftaten zusammenfassend gewürdigt.

Najbardziej widoczna różnica występuje w przepisach wyrażających normy sankcjonowane i sankcjonujące, które są najbardziej charakterystyczne dla obu kodeksów. W języku polskim pierwsza $\mathrm{z}$ nich występuje $\mathrm{w}$ postaci zdania podrzędnego z zaimkiem kto + czasownik w czasie teraźniejszym w trybie oznajmującym, druga $\mathrm{w}$ formie czasownika w czasie teraźniejszym w trybie oznajmującym. Na przykład przepis prawny stanowiący, czym jest przestępstwo kradzieży, brzmi:

\section{Przykład 16.}

Art. 278 . $§ 1$. Kto zabiera w celu przywłaszczenia cudzą rzecz ruchomą, podlega karze pozbawienia wolności od 3 miesięcy do lat 5.

W niemieckim kodeksie karnym norma sankcjonowana ma podobną postać, czyli zaimek wer i czasownik w czasie teraźniejszym w trybie oznajmującym, natomiast norma sankcjonująca ma postać strony biernej, składającej się z czasownika posiłkowego werden i imiesłowu biernego. Dla zilustrowania tych konstrukcji zacytujmy odpowiedni przepis z niemieckiego kodeksu karnego dotyczący kradzieży:

\section{Przykład 17.}

$\S 242$. (1) Wer eine fremde bewegliche Sache einem anderen in der Absicht wegnimmt, die Sache sich oder einem Dritten rechtswidrig zuzueignen, wird mit Freiheitsstrafe bis zu fünf Jahren oder mit Geldstrafe bestraft.

Analiza przekładu polskiego kodeksu karnego na język niemiecki wykazała, że w tym zakresie thumacze stosują się do konwencji obowiązującej w niemieckim kodeksie karnym. Realizują tym samym zasadę, która mówi, że w zakresie rejestru prawnego i prawniczego należy przestrzegać konwencji języka docelowego (por. Kierzkowska 2002, 56). Poniżej przykładowe tłumaczenie przepisów prawnych dotyczących kradzieży i zabójstwa:

\section{Przykład 18.}

Art. 278. $\S 1$. Wer eine fremde bewegliche Sache mit dem Ziel wegnimmt, sie sich zuzueignen, wird mit Freiheitsstrafe von 3 Monaten bis zu 5 Jahren bestraft.

Przykład 19.

Art. 148. $\S 1$. Wer einen Menschen tötet, wird mit Freiheitsstrafe nicht unter 8 Jahren, Freiheitsstrafe von 25 Jahren oder lebenslanger Freiheitsstrafe bestraft.

W tym miejscu należy zaznaczyć, że wyżej opisana forma normy sankcjonującej jest charakterystyczna dla niemieckiego kodeksu karnego, bowiem w austriackim kodeksie karnym norma ta ma zazwyczaj postać formy konkurencyjnej strony biernej składającej się z czasownika posiłkowego sein i bezokolicznika z partykułą zu. Oto cytat odpowiedniego artykułu z austriackiego kodeksu karnego: 
Przykład 20.

$\S 127$. Wer eine fremde bewegliche Sache einem anderen mit dem Vorsatz wegnimmt, sich oder einen Dritten durch deren Zueignung unrechtmäßig zu bereichern, ist mit Freiheitsstrafe bis zu sechs Monaten oder mit Geldstrafe bis zu 360 Tagessätzen zu bestrafen.

\section{Poziom tekstu}

Na poziomie tekstu aspekt kulturowy odzwierciedla przede wszystkim makrostruktura obu kodeksów. Struktura polskiego kodeksu karnego składa się z następujących jednostek systematyzacyjnych (od jednostki najwyższej do najniższej): część, rozdział, artykuł i paragraf. Natomiast niemiecki kodeks karny obejmuje więcej jednostek i dzieli się na (od jednostki najwyższej do najniższej): część (Teil), rozdział (Abschnitt), tytuł (Titel), paragraf $(\S)$. W thumaczeniu istotne jest zachowanie podziału ustanowionego przez ustawodawcę, zwłaszcza w obrębie zdania, ponieważ wprowadzając zmiany w przepisach prawnych, przy określaniu lokalizacji tych zmian ustawodawca mówi o zdaniu, używając sformułowań: „w drugim zdaniu” lub „po przecinku w zdaniu podrzędnym" (por. Kierzkowska 2002, 83-84). W przekładzie polskiego kodeksu karnego na język niemiecki ustalona przez ustawodawcę struktura została zachowana, nawet w obrębie przepisów mających postać zdania wielokrotnie złożonego. Za przykład może posłużyć artykuł 95a i jego odpowiedni przekład:

\section{Przykład 21.}

Art. 95a. § 1. Skazując sprawcę na karę pozbawienia wolności bez warunkowego zawieszenia jej wykonania za przestępstwo skierowane przeciwko wolności seksualnej, popełnione w związku z zaburzeniami preferencji seksualnych, sąd może orzec umieszczenie sprawcy, po odbyciu tej kary, w zakładzie zamkniętym albo skierowanie go na leczenie ambulatoryjne, w celu przeprowadzenia terapii farmakologicznej lub psychoterapii, zmierzających do zapobieżenia ponownemu popełnieniu takiego przestępstwa, w tym w szczególności poprzez obniżenie zaburzonego popędu seksualnego sprawcy.

Art. 95a. § 1. Das Gericht kann bei der Verurteilung eines Täters zu einer Freiheitsstrafe ohne bedingte Aussetzung der Vollstreckung wegen einer Straftat gegen die sexuelle Selbstbestimmung, die im Zusammenhang mit den Störungen der sexuellen Präferenzen begangen wurde, anordnen, das der Täter nach Verbüßung der Strafe in einer geschlossenen Anstalt untergebracht wird oder sich einer ambulanten Heilbehandlung unterzieht, um eine pharmakologische Therapie oder Psychotherapie durchzuführen, die einer erneuten Begehung einer solchen Straftat vorbeugen soll, insbesondere durch Senkung des Geschlechtstriebes des Täters. (...)

\section{Podsumowanie}

Przeprowadzona analiza aspektów kulturowych na wybranych przykładach pochodzących z polskiej ustawy Kodeks karny oraz jej przekładu na język niemiecki wyraźnie pokazuje, że aspekty te występują na wszystkich poziomach prawnego tekstu 
Katarzyna Siewert, Analiza kuturowych aspektów w niemieckim przekładzie...

specjalistycznego: leksykalnym, składniowym i w samej jego strukturze. Tłumaczowi, który nie zna i nie ma świadomości tych zjawisk, wszystkie przejawy kultury zawarte w tekście prawnym będą sprawiały trudności nie tylko $\mathrm{w}$ recepcji, lecz także w produkcji tekstu docelowego. Nieznajomość konwencji językowych przyjętych przy formułowaniu tekstów prawnych i prawniczych, które zostały usankcjonowane przez tradycję i stanowią element kultury prawnej, może prowadzić niekiedy nawet do dokonania błędnego tłumaczenia. Dlatego też zwłaszcza tłumacz-ekspert zajmujący się przekładem tekstów prawnych i prawniczych odzwierciedlających kulturę prawną musi posiadać nie tylko dogłębną wiedzę specjalistyczną, ale i kulturową.

\section{Bibliografia}

Fleischmann, Eberhard, Schmitt, Peter A. Schmitt. 2004. Fachsprachen und Übersetzung. W: Ein internationales Handbuch zur Übersetzungsforschung, red. Kittel, Harald, House, Juliane, Schultze Brigitte, 531-542. Berlin: Walter de Gruyter.

Gizbert-Studnicki. 1993. Das Problem des Übersetzens und das juristische Weltbild. W: Übersetzen, verstehen, Brücken bauen. Geisteswissenschaftliches und literarisches Übersetzen im internationalen Kulturaustausch. Teil 1, Frank, red. Frank, Armin Paul et a., 305-313. Berlin: Erich Schmidt.

Grucza, Sambor. 2006. Idiolekt specjalistyczny - idiokultura specjalistyczna interkulturowość specjalistyczna. W: Teksty specjalistyczne w kontekstach międzykulturowych $i$ ttumaczeniach, red. Lewandowski, Jan, Kornacka, Małgorzata, Woźniakowski, Waldemar, 30-49. Warszawa: Katedra Języków Specjalistycznych Uniwersytetu Warszawskiego.

Hattenhauer, Hans. 1980. Die geistesgeschichtlichen Grundlagen des deutschen Rechts. Heidelberg. Karlsruhe: Müller.

Hönig, Hans G., Kußmaul, Paul. 1982. Strategie der Übersetzung. Ein Lehr- und Arbeitsbuch. Tübingen: Gunter Narr.

Ipsen, Knut. 2000. Recht als Kulturelement. W: Festschrift für Otto Sandrock zum 70. Geburtstag, red. Berger, Klaus P., Elsing, Siegfried H., Ebke, Werner F., Grossfeld, Bernhard, 407-420. Heidelberg: Verlag Recht und Wirtschaft.

Kalinowski, Stefan, Wróblewski, Jerzy. 1988. Zagadnienia polskiej terminologii prawnej i prawniczej. W: Studia Prawno-Ekonomiczne, t. 34, 17-34. Wrocław et al.: Wydawnictwo Polskiej Akademii Nauk.

Kautz, Ulrich. 2002. Handbuch Didaktik des Übersetzens und Dolmetschens. München: Iudicium.

Kierzkowska, Danuta. 2002. Ttumaczenie prawnicze. Warszawa: Wydawnictwo TEPIS.

Koller, Werner. 2011. Einführung in die Übersetzungswissenschaft. Tübingen. Basel: A Francke.

Kubacki, Artur D. 2012. Ttumaczenie poświadczone. Status, kształcenie, warsztat i odpowiedzialność ttumacza przysięgłego. Warszawa: Wolters Kluwer.

Markstein, Elisabeth. 2006. Realia. W: Handbuch Translation, red. Snell-Hronby, Mary, Hönig, Hans G., Kußmaul, Paul, Schmitt, Peter A., 288-291. Tübingen: Stauffenburg.

Nord, Christiane. 2011. Funktionsgerechtigkeit und Loyalität. Theorie, Methode und Didaktik des funktionalen Übersetzens. Berlin: Frank \& Timme. 


\section{Comparative Legilinguistics 17/2014}

Pieńkos, Jerzy. 1999. Podstawy juryslingwistyki. Warszawa: MUZA SA.

Pommer, Sieglinde. E. 2008. Translation as Intercultural Transfer: The Case of Law. $\mathrm{W}$ : SKASE Journal of Translation and Interpretation. 3(1). http://www.pulib.sk/skase/Volumes/JTI03/pdf_doc/ Pommer.pdf (dostęp 06.05.2013).

Prunč, Erich. 2000. Vom Translationsbiedermeier zu Cybertranslation. W TEXTconTEXT $14=N F 4,3-74$.

Reinart, Sylvia. 2009. Kulturspezifik in der Fachübersetzung. Berlin: Frank \& Timme.

Reiß, Katharina, Vermeer, Hans. J. 1984. Grundlegung einer allgemeinen Translationstheorie. Tübingen: Niemeyer.

Sandrini, Peter. 1999. Translation zwischen Kultur und Kommunikation: Der Sonderfall Recht. W: Übersetzen von Rechtstexten. Fachkommunikation im Spannungsfeld zwischen Rechtsordnung und Sprache, red. Sandrini, Peter, 9-43. Tübingen: Gunter Narr.

Sandrini, Peter. 2006. LSP Translation and Globalization. W: Insights into Specialized Translation, red. Gotti, Maurizio, Šarčević, Susan, 107-120. Bern: Peter Lang.

Sandrini, Peter. 2010. Fachliche Translation. W: Diskurs und Terminologie beim Fachübersetzen, red. Maliszewski, Julian, 31-51. Frankfurt am Main: Peter Lang.

Stolze, Radegundis. 2005. Transparentes Übersetzen im Bereich des Rechts. W: Kultur, Interpretation, Translation, red. Salevsky, Heidemarie, 275-290. Frankfurt am Main et al.: Peter Lang.

Stolze, Radegundis. 2010. Kulturelle Aspekte beim Fachübersetzen. W: Diskurs und Terminologie beim Fachübersetzen, red. Maliszewski, Julian, 11-30. Frankfurt am Main: Peter Lang.

Strafgesetzbuch, http://www.gesetze-im-internet.de/bundesrecht/stgb/gesamt.pdf (dostęp 04.05.2013)

Strafgesetzbuch, http://www.jusline.at/Strafgesetzbuch_\%28StGB\%29_ Langversion.html (dostęp 07.06.2013).

Strafgesetzbuch und Übertretungsgesetzbuch. Kodeks karny i kodeks wykroczeń. 2012. Warszawa: Wydawnictwo C.H. Beck.

Vermeer, Hans J. 1986 . Übersetzen als kultureller Transfer. W: Übersetzungswissenschaft: Eine Neuorientierung, red. Snell-Hornby, Mary, 30-53. Tübingen: Francke.

Waibel, Harry. 2007. Kritik des Anti-Faschismus der SED. 1-53. Stiftung für Sozialgeschichte des 20. Jahrhunderts - sozial.geschichte.extra. http://www.stiftung-sozialgeschichte.de/ZeitschriftOnline/pdfs/

Kritik\%20des\%20Anti-Faschismus\%20der\%20SED\%203.12.07.pdf （dostęp 30.04.2013).

Wotjak, Gert. 1993. Interkulturelles Wissen und Sprachvergleich. W: Studien zum romanisch-deutschen Sprachvergleich, red. Rovere, Giovanni, Wotjak, Gert, 5568. Tübingen: Niemeyer. 
Katarzyna Siewert, Analiza kuturowych aspektów w niemieckim przekładzie... 